\title{
Politics and governance of social assistance in crises from the bottom up
}

\author{
Jeremy Lind \\ BASIC Research
}

February 2022

Implemented by

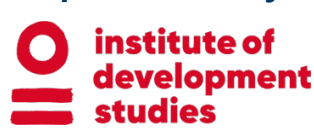




\section{Summary}

This paper reviews existing perspectives on the politics and governance of social assistance in crises from the bottom up - from sub-national regions (or states/provinces) down to districts, sub-districts, towns, and villages. It begins by examining recent literature on the politics of social protection, which is mostly based on assessment of political dynamics and relationships in settings that are peaceful and only minimally affected (or unaffected) by conflict-related violence. Key insights from political economy analysis of humanitarian assistance, alongside the 'political marketplace' - a more recent concept used to understand governance in fragile and conflict-affected settings (FCAS) - are introduced to deepen understanding of politics specifically in situations where statehood is both limited and negotiated. The second part of the paper reviews various insights into sub-national and local governance, focusing on the role of non-state actors in provisioning and distribution at the edges of state power, delivery configurations in these settings, and the rationalities of local governance and 'real implementation'. Understanding the arrangements and dynamics of governance subnationally and locally is essential for designing and planning the provision of social assistance in ways that are more likely to be politically and socially acceptable while also being inclusive and delivering value for money. The conclusion draws together these various perspectives on politics and governance from the bottom up to consider the implications and questions for further research on social assistance in crises.

\section{About the author}

Dr Jeremy Lind is a development geographer of the Horn of Africa, focusing on conflict, violence, and livelihoods, particularly in pastoralist areas. He has more than 20 years of academic research, advisory work, and project management experience, working with a range of government and non-governmental actors at the national and sub-national levels in the Horn of Africa as well as scholars and advocates in the region. He is Research Director for the Better Assistance in Crises (BASIC) Research programme. 


\section{Contents}

1. Introduction $\quad 4$

2. Politics of social assistance $\quad 6$

2.1 Politics, state power, and social protection programming 6

$\begin{array}{ll}2.2 \text { Local politics in fragile and conflict-affected settings } & 7\end{array}$

3. (Local) governance in crisis-affected settings 11

3.1 'Making do' and governance through multiple public authorities 11

3.2 Delivery configurations and struggles in local governance arrangements 13

3.3 Rationalities of local governance and 'real implementation' 14

4. Conclusion $\quad 15$

$\begin{array}{ll}\text { References } & 17\end{array}$ 


\section{Introduction}

This paper reviews different perspectives on politics and governance that can contribute to a critical understanding of sub-national and local-level politics of social assistance in FCAS or crisis settings. In these places, from 'the bottom', the politics of social assistance might look very different from normative understandings that are implicit in large and often externally supported programmes, which are often designed based on experiences of the delivery chain in more peaceful settings (or settings less affected by conflict-related violence), and where governance is bounded by fixed structures and settled institutional arrangements. For the purposes of this paper, 'social assistance programmes' encompass social transfers, public works, fee waivers, and subsidies, and are often directed and coordinated by national governments. In areas of protracted crisis and conflict, social assistance also generally encompasses humanitarian assistance, which often uses the same modalities as state-driven social assistance programmes but usually with a greater emphasis on social transfers than other mechanisms such as subsidies or waivers (Slater and Sabates-Wheeler 2021).

From the perspective of institutionalised practice and programming in social assistance as part of social protection, delivery is conceived as a sequential chain of activities or steps. For example, the delivery systems framework identifies nine stages of implementing social assistance programmes, covering assessment, enrolment of beneficiaries, the provision of benefits and/or services, and ongoing management of beneficiaries' compliance, updating of client lists, grievance mechanisms, and decisions and notifications on removing clients (Lindert et al. 2020). Each of these steps conceals considerable infrastructure needs, both social and material, whose establishment and maintenance can be difficult and fraught, particularly in harder-to-reach FCAS (Donovan 2015; Jaspars 2018). Therefore, it is misleading to consider the delivery of social assistance at the sub-national and local levels without considering the politics of 'real implementation'. This includes being cognisant of how authority is not something inherent or independent of social assistance programmes but rather is produced (created, sustained, maintained, or challenged) through these interventions.

Politics - or contestations involving 'the control, allocation, production, and use of resources and the values and ideas underlying those activities' (Tria Kerkvliet 2009: 227) - matter to the introduction, extension, and implementation of social assistance programmes, whether they are coordinated by the state or by other actors, including humanitarian agencies. First, the very existence of a programme can be a form of political communication. From the bottom up, a social assistance programme could be perceived as the assertion of power by particular public authorities, not all of whom will be accountable or have popular consent to govern. Second, targeting processes are an opportunity to redraw boundaries and rules determining who is worthy of being included and who should be excluded. Even if targeting decisions follow technocratic guidance, transfers are often subject to redistributive pressures once they are given; in other words, sharing practices that are either part of horizontal support networks or coerced by local authorities. In these ways, transfers are inseparable from local-level distributional politics. Third, implementation can give rise to a host of grievances and complaints. Rarely are these addressed and contained within a technocratic grievance mechanism; instead, they spill over into a field of social and political relationships through which people seek accountability.

Yet, what is known about the politics of social assistance - at least those programmes encompassed within state social protection systems - is mostly informed by a focus on the national level, including connections and flows of influence between national governments and transnational policy actors and networks.

Moreover, this knowledge draws from research focusing on settings that are characterised by minimal levels of conflict-related violence. Studies on humanitarian cash transfer programmes (Jaspars 2018), as well as safety net programmes for refugees (Cetinoglu and Yilmaz 2020; Cuevas et al. 2019; Zaman et al. 2021), provide complementary insights into the politics of social assistance in crises. These studies emphasise the nuances of delivering assistance in contexts characterised by conflict-related uncertainties and political instability, the dilemmas of negotiating access to populations in areas under the control of non-state armed groups, and the politics of targeting and exclusion.

The politics of social assistance unfold at all levels - not only within and between national governments and related organisations (Harvey and Mohamed 2021), but at the level of sub-national political administration 
too. Social assistance is shaped by political processes but also feeds into politics, both at the national and local levels (Barrientos and Pellissery 2012), involving not only state agents but a range of other public authorities in planning and delivering assistance - customary authorities, international and national nongovernmental organisations (NGOs), other humanitarian agencies, armed groups, political movements, and religious networks and groups. Distributional politics at the sub-national level and below will shape the outcomes of social assistance programmes, including who benefits, who misses out, as well as relations between society and different public authorities.

While many analyses focus on 'official politics', referring to more organised activity directed by authorities in organisations concerning the 'making, implementing, changing, contesting, and evading [of] policies regarding resource allocations' (Tria Kerkvliet 2009: 231), there is less attention to 'everyday politics'. These refer to the less organised and directed ways in which people embrace, comply with, adjust, and contest 'norms and rules regarding authority over, production of, or allocation of resources' (ibid.: 232). Whereas 'official' and 'everyday' politics are not binary opposites - and in fact both types enmesh in most places - they are useful for bringing attention to how formal programmes and structures and official rules are adapted. As we will see later, this is relevant in assessing what happens to programmed forms of social assistance at the margins, particularly in FCAS, where various public authorities beyond the state are involved in implementation. Both types of politics - the official and the everyday - are significant to understanding what happens to a social assistance programme beyond its introduction 'on the ground' to its implementation, as well as its impacts and influences, both intended and unintended.

From the bottom up, how might the politics of social assistance appear in places affected by fragility and conflict? Furthermore, what happens when 'formal' social assistance is introduced in these settings? We know that conflict and political instability are defining features of 'crisis' in most of the contexts that are of interest to BASIC Research, including the Democratic Republic of Congo (DRC), Ethiopia, north-eastern Nigeria, Mali, Somalia, South Sudan, and Yemen. In these places, public authority is contested and often fragmented. Social assistance is something that is political and is negotiated between and among diverse public authorities. Different authorities, including rebels and other non-state armed groups and movements, may seek to control the provision of social assistance, not only to reward their supporters but also to establish and/or deepen their legitimacy. Centralised political authorities, with the help of development partners, may seek to extend social assistance to previously marginalised areas and populations as a way of dampening dissent but also extending the authority of 'state' actors. Similar points are well-established in critiques of humanitarian assistance (Duffield 2007; Keen 2008), and of value to examining the politics of social assistance provision by states and their development partners in FCAS.

This paper reviews existing perspectives on the politics and governance of social assistance in crises at the sub-national and local levels. It is based on a rigorous review of scholarly and grey literature that was identified through keyword searches of academic search engines, online discussion groups, and as recommended by experts in the field. ${ }^{1}$ These were carefully reviewed using an approach loosely modelled on thematic content analysis (Vaismoradi, Turunen and Bondas 2013), whereby the literature was reviewed using pre-identified codes (or themes) and additional themes were identified through the process of further review and reflection.

The paper begins by examining key insights from recent studies on the politics of social protection. While many of these focus on the national level and are based on research undertaken in relatively peaceful contexts, they do provide analytical resources to understand political behaviour and elites' responses to social protection measures, and specifically the introduction and implementation of social assistance programmes, at the sub-national level. Additional insights from political economy assessments of famine and humanitarian assistance as well as 'political marketplace' thinking - referring to a system of governance characterised by monetised patronage to secure political loyalty or cooperation (de Waal 2014) - are then reviewed to deepen consideration of FCAS, and the implications for externally supported social assistance. This thinking features in recent debates on state-building as well as externally driven peace processes and peace-building interventions. It is introduced as a way of expounding governance dynamics and the

\footnotetext{
${ }^{1}$ An earlier version of the paper was presented in April 2021 as part of the BASIC Research webinar series. I wish to thank the participants who suggested framings as well as further literature to review, which has helped to strengthen the paper.
} 
behaviours of conflict actors, and thus raise questions for how public authorities might relate to efforts to introduce or change social assistance provision in FCAS. The paper then turns to key insights from the literature on hybrid (and everyday) governance, which examines how public authority, and the provision of services is exercised through states operating alongside other informal and non-state actors (Meagher 2012). These offer complementary views on how the delivery of public services and assistance is configured in places of fragmented and contested authority. The involvement of multiple authorities (state/non-state, formal/informal, armed/civil, international/national/local) in the governance of public goods, and the various combinations of these in delivery configurations, points to the need to test technocratic assumptions inherent in frameworks that are used to implement programmed (or 'formal') social assistance. The conclusion brings together these assorted viewpoints on politics and governance to consider angles and questions for further research on the politics and governance of social assistance in crises from the bottom up.

\section{Politics of social assistance}

\subsection{Politics, state power, and social protection programming}

This section reviews what is known about the introduction and implementation of national social protection programmes, much of which is drawn from assessing stable political contexts that do not experience armed conflict-related violence. Some implications of this literature are identified in regard to social assistance in crises before the next section explores politics and governance specifically in fragile or conflict-affected contexts. Recent debate on the politics of social assistance focuses on the national level and the degree to which social assistance adheres with the interests of governing elites as well as methods for guarding their power. A broad finding in the literature is that the nature of domestic politics - including how national political leaders relate to transnational policy actors and networks - determines the adoption and timing of social protection programmes as well as the specific type of programming that is pursued and the degree to which these are expanded (Hickey et al. 2019: 15). Lavers and Hickey (2020) specify three key drivers for the introduction and expansion of social protection programmes in east and southern Africa, focusing on the interplay of domestic politics and transnational influences. These include: (1) the existence of meaningful political competition; (2) a distribution crisis that is perceived as a threat to ruling elites; and (3) the existence of a transnational policy coalition that advocates for reform. Elsewhere, Hickey et al. (2019) find that social assistance is part of the politics of patronage - something that can build regime legitimacy, secure political allegiance, or win over electoral support. Social assistance both stems from and helps to entrench different political forms, not all of which are aligned with liberal notions of citizenship and strengthening the social contract between the state and society (Hickey et al. 2019: 23). As Lavers and Hickey (2016: 391) explain, 'elite factions will view social protection as a means of buying political support, rather than as a way of promoting a new social contract between the state and its citizens'.

A complementary aspect of the debate focuses on the relative influence of transnational actors, particularly donors (Devereux 2020). Multilateral and bilateral donors can influence the social assistance policy process in aid-recipient countries, particularly at the stage of pushing the idea of social transfers onto government agendas and national political debate (Abdulai 2021; Cherrier 2020). Whereas donors advocate for specific forms of social assistance, whether they are successful hinges on whether their ideas align with the ideas and interests of dominant political figures, or the degree to which regimes in aid-recipient settings need external resources. Lavers and Hickey (2020: 26) found no cases among the countries they reviewed where donor influence alone was enough to advance institutionalisation of social protection measures. Thus, transnational influences cannot be viewed in isolation from the actors, networks, and discourses that determine domestic policy processes (Keeley and Scoones 2000). Donors can promote particular social assistance programmes through a combination of ideas, designs, and financial leverage. Yet it is the politics of policy processes within national settings that determines the scope and limits of external influence (Hickey et al. 2019).

Lavers (2020) borrows the concept of 'state infrastructural power' from the social theorist Michael Mann to examine state capacity and the elements that are required for effective delivery of social transfers. Mann (1984: 113, in Lavers 2020: 3) defines state infrastructural power as 'the capacity of the state actually to penetrate civil society, and to implement logistically political decisions throughout the realm'. In relation to the 
delivery of social transfers, Lavers identifies three elements that are required for effective distribution: financial, technical, and human resources to implement programmes; intra-state relations - lower levels of political administration need to stick to plans with minimal adaptation; and state-society relations - states need to be able to work with and through society, which is contingent on the strength and organisation of the local state, other sources of authority, and relations between these.

Taken together, these dimensions speak to the historically embedded and relational nature of state power. In systems for distributing social transfers, local, non-state authorities may compensate for the weak infrastructural power of the state (Porisky 2020).

Lavers, Mohammed and Selassie (2020) use the example of Afar in Ethiopia's predominantly pastoral eastern lowlands to show how central state authorities, and their local-level counterparts, must work alongside and through a variety of indigenous elites to implement the Productive Safety Net Programme (PSNP). Many formal structures for PSNP implementation, such as targeting committees, do not function; there is a high turnover of local officials, and their operational capacities are thin. To address the limited infrastructural power of the central state in Afar, implementation of the PSNP leans on clan structures, which have greater legitimacy and capacity. Yet, within Afar, this has given rise to variable outcomes. In some areas, the legitimacy of clan leaders involved in PSNP implementation has contributed to more positive local outlooks of the programme - particularly in places where clan leaders are different from local state administrators. However, in other areas, the involvement of unaccountable individuals who fill multiple coexisting roles as state, party, and clan leaders has subverted the PSNP's intended distribution, with local officials selecting beneficiaries without negotiating with state or other public authorities (ibid.: 23).

Given the varying make-up of clan authority in Afar, and its merging with local state administration sometimes both roles taken by the same individual(s) - there is a potential for PSNP implementation through clan structures to generate tensions and exclusions. Afar political elites are regarded as being 'co-opted' and tamed: those in proximity to state infrastructural power have used this to the advantage of their own narrower interests, whether to attain the best irrigation plots, to acquire positions in local government structures, or to develop business links with national political elites (Rettberg 2020). Dovetailing with these patterns of local elite enrichment through co-opting resources afforded by the central state, past evaluations of the PSNP in Afar have documented practices of favouritism and nepotism in targeting in some places (Sabates-Wheeler, Lind and Hoddinott 2013). Similarly, in Kenya, particularly in areas historically marginalised by the central state, the involvement of informal local authorities in social transfer programmes had 'led to inclusion and exclusion errors, as local actors opt to include family members or friends in the programme, leading to the exclusion of the most vulnerable households' (Porisky 2020: 29). Nonetheless, just as in Afar, outcomes were uneven, because in some places locally embedded actors involved in targeting had contributed to a distribution that was perceived as 'fair' and more in keeping with local definitions of poverty (ibid.).

Thus, the politics of social protection - even in places that are more peaceful and where national political actors take leadership in directing programmes - involve issues of patronage, favouritism, and elite capture. Given the speed with which national social protection programmes have been introduced in recent years, particularly in sub-Saharan Africa (Devereux 2020), one could overlook the fact that implementation in many places is highly uneven and depends on a host of actors beyond the state. These dynamics come into sharper relief in FCAS, where state authority is contested and where transnational actors (including humanitarian agencies and other international organisations) are heavily involved in introducing and implementing social assistance programmes.

\subsection{Local politics in fragile and conflict-affected settings}

Prevailing insights into the politics of social assistance, as already discussed, are useful up to a point for understanding the dynamics of social assistance in fragile and conflict-affected contexts. Political orders in these settings are characterised to varying extents by insecurity of officeholders, turmoil, the use of violence to challenge or entrench power, and external interventions, not all of which are benign. All these characteristics contribute to a dynamic power landscape and require a reassessment of both the forces driving the introduction of social assistance programmes and the infrastructural power to implement these. Implementation is likely to be fragmented and unequal in settings with imperfect political competition (where power is concentrated) (Barrientos and Pellissery 2012). What is likely to happen in contexts where power 
(while possibly being more diffuse) is the subject of violent contestation and struggles in the wider social environment?

Studies of the political economy of famine and humanitarian assistance provide some perspective. As Jaspars et al. (2020: 2) show, building on the work of Duffield (1994) and Keen (1994), 'the political economy of famine and relief can be seen as the maintenance of power by asset-stripping of politically weak populations'. They explain that some groups are excluded from aid agency-led relief distributions because of their existing political disadvantage. Thus, 'It is... important to understand who [has] the political muscle, how they control resources, and why, before attempting to target aid at the most vulnerable' (ibid.: 32). Humanitarian assistance itself can become a resource that fuels conflict as it engenders struggles and competition over distribution within and between groups. Political economy analysis can generate insights into these dynamics and mechanisms of inclusion and exclusion. Given its proximity to - and, indeed, inseparability from - dynamics shaping situations of conflict and peace, political economy analyses show how relief itself is subsumed within processes that create, sustain, and transform political relationships over time. In conflict-affected settings, political economy analyses cover a range of issues, including protection rackets, informal tax, aid diversions, and the payment of ransoms (Carbonnier 2015). Just as the provision of relief assistance to conflict-affected populations is inseparable from the business of politics and conduct of war in conflict settings, so too can the provision of social assistance (directed either by states or international organisations) be seen as part of how power and vulnerability are produced in FCAS.

Three key areas of emphasis in analyses of the political economy of humanitarian aid are equally useful for exploring the politics of social assistance. First, they focus on the interests and incentives facing different groups in society (and particularly political elites), and how these create dynamics that may encourage or hinder certain delivery arrangements and resource distributions. Second, they consider the roles and the relationships between formal and informal institutions that shape political struggles and behaviour. Third, they consider how values and ideas influence the political calculations of different public authorities, tracing their impact through to the adoption and implementation of programmes.

These features of political economy analysis are close to recent thinking around the 'political marketplace'. Alex de Waal, the primary proponent of this concept, offers it as a way of understanding elite politics and governance in fragile settings. The idea of a political marketplace was further probed in the recent Conflict Research Programme funded by the UK Foreign, Commonwealth \& Development Office (FCDO). Broadly, it refers to a system of political allegiances and services that are exchanged for material reward in a competitive manner. To date, the concept has been used to a limited extent to understand crises and humanitarian responses (de Waal, Sarkar and Newton 2021) but not in relation to social assistance. Yet, the emphasis in political marketplace thinking (as detailed below) on means to power, transnational influences, and interventions in conflict settings - as well as practices of extraversion by political elites in relation to aid and external responses - are useful complements to existing study of the politics of social assistance in more peaceful settings.

Within a political marketplace, the functions of the state are instrumentalised in such a way that power is bought and sold according to the laws of supply and demand (Kaldor and de Waal 2020). Thus, while seeming to possess the qualities of a chaotic system, the structure of political marketplaces often endures over long periods of time, and 'responds in broadly foreseeable ways to external and internal shocks' (de Waal 2016: 3). Research into the political marketplace in different conflict settings focuses less on how to transition to more institutionalised and ordered states and more on how systems of governance function and the effects of external interventions on these. This is relevant to understanding distributional politics at the sub-national level and how externally supported, programmed types of social assistance are received and reformulated in relation to the logic of existing governance.

Reflecting on experiences in more peaceful, democratic settings, Barrientos and Pellissery (2012: 24) caution that an exclusive focus on elites (as in the political marketplace) and incentives is too limited to unfurl the political dynamics around social assistance; they hold that social contracts and pacts, key events, ideology, and knowledge are significant, as well, to understanding the politics of social assistance. Hickey et al. (2019) point out that ideas and ideologies are significant for understanding variation in the uptake of social assistance programmes in countries in east and southern Africa. They note that in many countries in the region, even in places where there are entrenched negative attitudes toward 'handouts', 'elites recognise 
collective responsibilities for certain categories of deserving poor, including even working-age adults and their dependants in times of drought' (ibid.: 20). Thus, inasmuch as political marketplace analysis is useful to expound elite political behaviour and dynamics in FCAS, a fuller understanding of the politics of social assistance requires attention to ideas and values within a particular political context. This would extend to consideration of gender and social inclusion - specifically, how inclusive, or exclusive are political and governance systems through which social assistance is provided? For example, one key question is who is elected or appointed to positions of influence, and how that is gendered and shared among people with diverse backgrounds. Furthermore, when elites do recognise collective responsibilities, who is considered to be part of that collective (by age, sex, ethnicity, political affiliation) and who is not?

Research on the political marketplace applies two other concepts to explain the nature of monetised and transactional politics as well as means to power in settings with 'marketplace' qualities: political budget and moral populism. Political budget refers to discretionary funds possessed by a politician that are usually spent on renting allegiances or buying political services (de Waal 2016). The connection with social assistance is clear in that variously positioned public authorities at the sub-national level may seek to influence targeting decisions as well as the allocation of other programme implementation resources in ways that benefit narrower factional interests.

Moral populism refers to 'the social and political power produced by invoking exclusivist and morally-imbued identities and values' (Centre for Public Authority and International Development 2021). The concept is useful in understanding the politics of social assistance because it examines the appeals of political actors - within the 'marketplace' or any other governance setting - to social norms when providing goods. Political actors' appeals 'take the form of justifications for their preferred distribution of resources or access to goods' and 'create insiders and outsiders, and boundaries or rules that determine who or what are deemed worthy of support, protection and development' (Kirk 2021). Appeals could include obligations and socially enforced responsibilities to care for the 'deserving poor' (Hickey et al. 2019). Moral populism and associated notions of deservingness may also be associated with social identities that are meant to exclude - and, hence, be especially potent in situations of conflict. Kaldor and de Waal (2020: 534) find that 'contemporary conflicts are characterised by a specific type of fragmented political identities that are exclusivist, singular and make a claim to be fixed'. Hoffmann et al. (2020) show how this can work, in their study of the relationship between ethnicity and violent conflict in the DRC. They argue that ethnicity is a form of capital and is invoked in discourses and practices in ways that dismantle 'the artificial dualism between the symbolic realm of identities and the material realm of the economy' (ibid.: 540).

Within a political marketplace setting, deservingness for social assistance could be interpreted according to the prevailing logic of cornering and claiming resources based on highly fragmented identities. Ethnicity, like other social identities that are invoked in the appeals of political actors, is a currency to negotiate access to material resources, including social assistance. Thus, as elaborated in the next section, guidelines for implementing national programmes may be interpreted and applied differently by sub-national political actors.

The nature and dynamics of politics and power within the political marketplace requires taking a different view of the influence and impacts of external interventions such as outside mediation and efforts in parallel to strengthen a 'political settlement' (Bell and Pospisil 2017), which may encompass social assistance programmes. While not by design, these often fix the relationships between fragmented identities and subunits of states. As Kaldor and de Waal observe:

Contemporary peace agreements do not end violence; rather they provide a legalistic veneer to a newly established set of power relations based on the combination of disassembled political units, fragmented identity, and crony capitalist networks, which provide the core components of the political marketplace.

(Kaldor and de Waal 2020: 534)

Foreign aid - at least parts of it - is taken and allocated as political budget to cement alliances and minimise threats to the existing balance of power, as Markakis, Schlee and Young (2021) show in South Sudan:

...'rent' in the form of foreign aid was the main asset associated with statehood. There was little else in terms of statehood. Policies that were formulated to benefit South Sudan usually had an ulterior goal. Disarmament, demobilization, and reintegration (DDR) is part of every standard international 
peacemaking agenda, because it aims to reduce the number of combatants. But in South Sudan it worked as a kind of pension scheme for non-combatants (such as cooks) and for aged or incapacitated soldiers... In anticipation of things to come, no political faction dreamt of actually reducing its fighting force.

(Markakis et al. 2021:14)

From the vantage point of the political marketplace, directing resources as political budget to secure the allegiance or cooperation of political actors is both rational and necessary to manage persistent uncertainty. Again, taking South Sudan as an illustration, de Waal (2015) explains:

Any bubbles of technocratic integrity that might exist, here and there within the system, depend entirely on the goodwill and political clout of their individual mentors. When those individuals move, or political circumstances change, those bubbles are pricked. Foreign technical advisors and other well-wishers made the error of assuming that the cash-in-hand and kleptocratic system of government, and the failures to reform and professionalise the armed forces, were a failure of government that could be remedied by advice and resources. That is not the case: these were elements of a successful political strategy. The South Sudanese were perfectly capable of running institutions and developing their country. But... the leadership had other priorities.

(de Waal 2015: 100)

As the example of South Sudan shows, conditions of war are useful toward the end of disassembling the state, whose functions become instrumentalised in pursuit of power and material resources. Kaldor and de Waal (2020: 534) argue that 'contemporary wars should be seen as wars of disassembly rather than state building in the Western tradition'. The idea of the political marketplace and related notions of political budget and moral populism therefore provide new conceptual tools with which to understand the impacts and influences of social assistance programmes on political systems in FCAS. They also raise difficult questions around efforts to introduce or reform social assistance programming in such settings. Funds for social transfers as well as for programme implementation may be captured by political elites as political budget; populist appeals may be invoked to strengthen the moral standing of public authorities that seek to target transfers to particular groups, thereby generating new exclusions and inclusions. These risks ultimately point to how the provision of social assistance is more than simply a matter of financial resources, technical capacity, and proficiency; it is inseparable from politics generating vulnerability alongside power and, hence, is far from benign.

Programmed forms of social assistance, either by states or international aid organisations, are not introduced into and/or delivered in a vacuum. Even the most fragile settings that are beyond the reach of the state are intensely governed and are rife with political agency that will influence how social assistance is implemented, for whom, and in whose interests. Moreover, fragile settings have many existing exchanges and flows of assistance, which are often lumped together, and referred to by the catchall phrase 'informal social protection'. These include highly organised and institutionalised forms of support such as zakat; ${ }^{2}$ they also encompass reciprocal support and mutual obligations as part of long-established but continuously evolving 'moral economy'. Although there is some attention to the possible impacts of formal safety net programmes crowding out private (informal) transfers (Grimm et al. 2021; Nikolov and Bonci 2020), there is weak understanding of how various forms of 'formal' and 'informal' social assistance intersect. They are often discussed as being somehow separate, mutually exclusive systems of support. But that is questionable, and particularly so in political environments where the 'marketplace' prevails. 'Formal' social assistance, especially in FCAS, might only be programmed and delivered through its engagement with various 'informal' authorities and spaces - through and in which a programme's objectives might be re-envisioned around a different set of values, interests, and aims. Likewise, 'informal' assistance might possess many of the features of 'formal' assistance, in terms of being regularised, predictable, regulated, and otherwise organised. While forms of informal assistance may not be bureaucratised or function according to a technocratic logic, and thus be equated with 'informality', they are often institutionalised and adaptable. Therefore, they are often better suited and more reliable in contexts that experience high degrees of turmoil and uncertainty.

${ }^{2} \mathrm{~A}$ form of almsgiving in Islam. 
Thus, insofar as formal social assistance uses informal structures and mechanisms and other ways in which they interact, there is a need for research to examine how systems of social assistance - spanning 'formal' and 'informal' designations - function at the local level in political environments with 'marketplace' characteristics. This is because the provision of social assistance at the sub-national level - funds for social transfers as well as related programme infrastructure - is often deployed as part of the political budget of public authorities, and because distributions (that include some groups but exclude others) are justified by populist discourses of who has a right to benefit. Relatedly, further research is needed into how interventions by the state and other transnational actors affect distributional politics at the sub-national level. The following section explores these questions from different perspectives on sub-national and local governance in crisis contexts.

\section{3. (Local) governance in crisis-affected settings}

\section{1 'Making do' and governance through multiple public authorities}

This section examines governance at the sub-national level and below, nearer to the level of direct implementation where programmes and systems meet beneficiaries as well as local officials who claim representative power. Sub-national governance matters to understanding the configurations for delivering different forms of social assistance (state, international, informal/customary), the relationships between the different actors involved in delivering these, as well as how the different forms entwine, and what this means for efforts to encourage more effective distribution of social assistance that is externally supported.

It is well-established in the literature that the state-centric view of what constitutes governance (not only at the sub-national level, but the national level as well) is very limited and, indeed, misleading in relation to the nature and workings of 'real governance' - and this is especially the case in FCAS where formal state mechanisms may be weak, contested or altogether missing. Rather, sub-national governance is carried out by a range of public authorities within, adjoining, and in opposition to, the state. Public authorities refers to any kind of body beyond the immediate family that requires a degree of consent (Centre for Public Authority and International Development 2021). The concept emphasises the functions of governance over their form; hence, it is 'neutral about the processes and actors involved - inside or outside the formal state, and across the public-private divide' (Unsworth 2010: 10). Public authorities encompass state and non-state actors alike, including clans and other customary authority structures, religious groups, aid agencies, international and national NGOs, civil society organisations, business associations, street bureaucrats, rebels, and vigilantes. As Lund (2006) notes, based on his study of public authority and local politics in different settings in subSaharan Africa, the 'state' does not function as a coherent institution in many political contexts. Rather, 'public authority becomes the amalgamated result of the exercise of power by a variety of local institutions and the imposition of external institutions, conjugated with the idea of the state' (Lund 2006: 686).

At the edges of state power there is an unspoken but widely observed duty to 'make do'. Assessing the state of bureaucratic governance in rural Niger, Olivier de Sardan (2011: 34) notes that, while the presence of the state is everywhere, it is 'not very effective, with its agents demobilised, frustrated and demotivated', and lacking the materials and means of carrying out their basic functions. In rural Burkina Faso, Samuelsen (2020: 946) observes that the state and public authorities relinquish their responsibility to provision of security and wellbeing, 'delegating to individuals and communities the responsibility for managing their own insecurities'. This underscores the value of a focus on public authority, which emphasises 'everyday forms of interaction between various claimants to public authority and end users' (Hoffmann and Kirk 2013: 13). Who people go to for services provided by local public authorities has to do with proximity, ethnicity, and common history (Gaventa and Oswald 2019). For example, in Pakistan, Gaventa and Oswald (2019) explain that several intermediaries broker access to services for poor and marginalised households, with success being a matter of contacting the right intermediary. In Myanmar, when local governance actors were seen as 'one of us', they were more likely to be approached by villagers with accountability requests or demands.

Recalling the redistributive moral populism described earlier, another example comes from chiefs' courts in South Sudan. These are often the only functioning justice mechanism at the local level, and they are reconstituted as 'hunger courts' during times of crisis to arbitrate the redistribution of resources to the 
hungriest people. Households unable to meet their food needs present their case to the court daily, seeking community resources or support in enforcing a claim against relatives that they are obliged to help. Newton et al. (2021: 6) explain, 'Litigants have their cases heard in turn, with hearings and judgements usually only taking a couple of hours and judgements executed within a few days'. Not only are hunger courts able to act expeditiously, but Newton et al. observe that local analysis of 'hunger' by chiefs corresponds closely with humanitarians' use of 'food insecurity' by weighing people's access to food over time.

'Making do' can entail collaborative arrangements - also called 'hybrid arrangements' - in which the state cedes certain responsibilities to local public authorities who are trusted and have greater means than the state to deliver. Menkhaus (2008) calls this a 'mediated state' model, in which a central government and informal local public authorities are not seen as antithetical but instead nested together in a negotiated division of labour. Such central state-local informal partnerships can contribute to building locally recognised and trusted modes of governance, which can be 'intrinsically messy, contradictory, illiberal, and constantly renegotiated deals' (ibid.: 78). 'Making do' can also consist of local state officials being facilitated by users or third parties to provide services - a type of informal privatisation of state functions that Olivier de Sardan (2011) observes in rural Niger. For the provision of social assistance, in many cases local officials will require additional support to satisfy their duties in targeting, ensuring that recipients carry out co-responsibilities as part of programme conditionalities/work requirements, and investigating complaints and appeals. The support required to implement social assistance can range from having access to vehicles and fuel to having a mobile phone and computer, and even the time to carry out additional administrative tasks. Thus, for programmed types of social assistance, third parties such as aid organisations or donors might fund local government to strengthen capacity to implement programmes.

Olivier de Sardan (2011: 33) explains that co-delivery arrangements at the local level can entail substitution (for weak or non-existent state-directed delivery), collaboration (in which non-state actors and local state actors work together on delivery), complementarity (where non-state actors and state actors have separate but complementary roles), and competition (where non-state involvement in delivering services and support challenges the role and authority of the state in doing so). The combinations of political actors and modes of governance observed at the sub-national and local levels reflect differing relationships between the centre and local levels. Boone (2003) identifies four broad categories of centre-local government relations, or 'political topography', which are potentially useful for understanding the types of co-delivery arrangements that could support the delivery of social assistance. In the first topography, institutionalised power-sharing, there is an accommodation between indigenous elites (who yield power) and the centre. In the delivery of social assistance, this could take the form of locally trusted authorities who help to steer targeting processes and address grievances and complaints for state-coordinated programmes, as in the example of Afar detailed earlier. Clan elders in Afar do not see the state apparatus as a competitor or a source of threat but rather as a source of support or an ally (Sansculotte-Greenidge and Fantaye 2012: 95).

A second topography, administrative occupation, is when the state is suspended over rural society, and central government retains control and is represented at different levels, from the capital city down to the region, district, and sub-district levels. In this type of relationship, characterised as it is by a thicker presence of political authority at the centre, local agents of the state would be assumed to have greater responsibility for delivery. Still, although it might be expected that implementation adheres to official guidelines and rules, local officials may yet exercise some discretion in adapting aspects of delivery to local realities. In Karamoja, north-east Uganda, the rapid extension of state power over the past 20 years has created a subordinate Karamojan political elite that performs the functions of administrative governance on behalf of the country's rulers. However, occupants of sub-national political offices in Karamoja do not depend only on the favour of the centre. Rather, their position also rests on their ability to address their constituents' needs and demands, which in certain cases entails realigning the objectives of state programmes to better suit the needs of the region's pastoralist and agro-pastoralist populations (Czuba 2019).

A third type of relationship (or topography), usurpation, is when indigenous elites are displaced by elites that are allied with the centre. In FCAS, this can be associated with upheavals - insurgencies and resistance from below and counter responses by the centre - and violence as part of state-building initiatives at the periphery. 
Finally, an extreme form of centre-local relationship (or topography) is non-incorporation or abandonment, in which no administrative hierarchy is present, and the state has little interest in the affairs of the subnational context in question. In south-central Somalia, collaborative arrangements involving clan, religious, and village leaders provide social welfare and emergency relief in the absence of assistance from a central state programme. They levy a general 'welfare tax', or qaaraan, as a type of community-based social insurance (Van den Boogaard and Santoro 2021: 21). Alongside collecting social welfare contributions, they also organise and collect revenues for emergency responses, sometimes in collaboration with NGOs, international agencies, and/or the government. Even in insecure areas, in response to devastating floods in Hirshabelle in 2016, cross-community and cross-clan collaboration on emergency responses was widespread (ibid.).

Thus, and especially in FCAS, governance is the purview of a whole assortment of public authorities, not all of whom are directed, coordinated, or supporting the plans and programmes of the state (national government). Co-delivery arrangements are commonplace because of the state's attenuated infrastructural power at the political and geographic margins, where 'making do' involves sharing responsibilities with and accommodating non-state sources of authority. While studies of the political economy of humanitarian assistance have long emphasised these points in relation to the governance of relief aid in conflict-affected settings, they are also significant for understanding the introduction and expansion of social assistance programmes and the politics involved in these.

\subsection{Delivery configurations and struggles in local governance arrangements}

While there is broad acceptance and, indeed, embracing of the need to nest the delivery of social assistance programmes in governance arrangements that are both appropriate and accepted at the local level, the decision on how to implement social assistance is much more difficult than simply identifying and ensuring that non-state public authorities are engaged in implementation. The nature of centre-local relations bears greatly on the political behaviour of local public authorities, determining the types of delivery arrangements that are most likely to succeed and, ultimately, the scope for social assistance programming. Not only will the strategies and logics of local public authorities vary depending on the type of centre-local relationship, but the particular accountabilities and sources of legitimacy of various local-level actors can be vastly different and disparate. This complicates efforts to constitute and strengthen delivery configurations. These refer to 'the combination of actors, institutions and means which permit the delivery of a public good', and they are made up of a number of 'component configurations' (Olivier de Sardan 2011: 32). Olivier de Sardan (2011) uses the example of childbirth in rural Niger to illustrate the local-level complexity of configurations to deliver health services as well as the bottlenecks and collective action problems that can arise around discrete components of these:

...the particular delivery configuration of the component 'evacuation of patient in case of obstructed pregnancy' includes as essential actors the midwife or nurse, people who are able to pay for the transport, the ambulance driver, elements of the FNIS (National Security Corps) and a functioning operating theatre and blood supplies at the referral centre. It also assumes the availability of the ambulance itself and the means of obtaining it. The general configuration for the delivery of babies involves in addition, traditional birth attendants (TBAs) and trained TBAs (matrones), the mayor's office, the President's Special Programme, various projects supporting maternal health, and even the chiefdom, as well as a staffed and equipped health unit, and maintenance procedures for the ambulance.

(Olivier de Sardan 2011: 32)

As the example above highlights, the multiplicity of actors to be involved raises tensions and struggles that are inherent not only between the centre and local level but also between different local-level public authorities. To take the example of the delivery of the PSNP in rural Ethiopia, a wide range of actors are involved across the programme's components including targeting, payments, public works, redressing grievances and complaints, and supporting livelihoods (asset-building) activities (Hoddinott et al. 2013). They include sub-district and community-level food security task forces that are meant to steer overall local-level implementation, development agents (employed by the government to buttress technical capacity of subdistrict administration in implementing national programmes, although they are often not from the areas where they are stationed), targeting and appeals committees, elders, and clan and religious leaders as well 
as influential women and young people who are meant to represent the views and interests of different local residents, transporters, local agents participating in digital payments, village savings and loan associations that provide access to credit, other local money-lenders, and extension professionals employed by the government or NGOs in health, agriculture, and natural resource management. These actors span the official sub-national political administration, other local political elites, businesspeople, local civil society and associational life, and NGOs. Whereas all of them have a defined role in some aspect of programme implementation, they operate from unique positions and distinct social and political ties. What also makes it challenging to assess the relationships within local delivery configurations is that individuals can and often do combine various roles, such as a member of a targeting committee who might also be a clan official and a businessperson/transporter with an interest in payments and contracts.

Furthermore, far from constituting a fixed and inherently more legitimate form of customary governance that is nearer to 'tradition', local public authority is emergent and indeterminate. It changes over time and is constantly renegotiated and produced anew, including in relation to external interventions as well as crises. Enria (2020) shows this in humanitarian programming responses to the Ebola epidemic in Sierra Leone from 2014 to 2016. Humanitarian agencies sought to involve local stakeholders to increase the acceptability and legitimacy of programmes and, ultimately, the efficiency of the response. Practically, this involved working through chiefs and other 'local influencers'. Yet the drive for community engagement was disconnected from the lived experiences of local authority structures. An uncritical embrace of chiefs and other influential local leaders implicated humanitarian agencies in producing power dynamics, effacing what was much more profound difference, contestation, and struggle.

While non-state orders are often assumed to be locally legitimate, they are contested just as state orders are, and may lack social legitimacy (Meagher, De Herdt and Titeca 2014). Thus, while there has been a broader turn in recent years to working with 'practical hybrids' - institutions that marry 'professional standards or scientific principles with the moral economy or established practices of the area' (Booth 2012: 89) - a perfunctory embrace of local hybrid arrangements risks downplaying or ignoring local struggles against public authorities that might have influence and power but are unaccountable and/or who actively discriminate and exclude. Or, as Meagher et al. (2014: 5) caution: 'Efforts to construct legitimacy by granting formal recognition to... dubious non-state orders may create low-cost solutions to governance problems in the short run, but risk eroding local legitimacy and consent in the long run'.

\subsection{Rationalities of local governance and 'real implementation'}

An unhelpful dichotomy is often evident in scholarly and policy debates between endogenous (local and informal) and exogenous (intervention) so that interventions are only seen in terms of the imposition of norms from outside, and badly adapted to local contexts (Olivier de Sardan 2011: 40). This dichotomy is apparent in discussions around the possible displacement effects of social assistance and humanitarian cash programming on informal support and other moral economy ties as well as the potentially corrosive influences of external assistance on local social and economic lives. Yet programmes are always folded into the strategies and logics of local actors. As the examples highlighted above show, rather than 'formal/informal' as a dichotomy for understanding the governance of social assistance from the bottom up, it is more useful to focus on who is providing assistance, and in whose interests. From the bottom up, social assistance looks different depending on who is providing it, why they are doing so (entailing the need to be alert to discourses as well as existing relationships, obligations, and power), and with what consequences (saving whose lives, protecting which livelihoods, maintaining power, and/or challenging or resisting authority).

Real practices, informal norms, and pragmatic rules beyond formal organisation and official regulations enable a focus on how social assistance is delivered in practice. These are in keeping with the approach of 'rationality in context', which is rooted in ethnography and begins from the premise that 'bureaucrats have good reasons for their seemingly "absurd" practices, once you understand the context in which they act' (Bierschenk and Olivier de Sardan 2019: 245). Implementation on the ground commonly diverges from official plans, regulations, and technical guidance. This is often viewed in misleading ways as something concerning 'gaps' or 'deficits' that can be addressed with more financial support and training rather than a considered set of decisions and actions that reflect local social and political demands and the means to negotiate these. 
Yet just as social policy reforms are more likely to have traction at the national level where national governments and civil societies 'own' and shape reforms in line with their interests, norms, and values (Hickey et al. 2019), so too will social policies at the sub-national and local levels gain acceptance where they are adapted and filtered through social norms and values as well as negotiated by various sub-national stakeholder communities. Making the case for examining the nuance and timbre of how social transfer programmes are implemented in Zambia, Pruce (2019: 211) notes that "Implementation becomes a filter that often alters intended policy"... with local leaders, bureaucrats and the public directly influencing policy development through their reactions as the nature and impact of a policy becomes visible'. Returning to the example of PSNP implementation in Afar, Ethiopia, the assumed shortcomings of targeting - as detailed in many evaluations - can be viewed differently when seen through local value systems and cultural notions of fairness in pastoral societies. Judged by vernacular understandings of need and culturally embedded notions of mutual obligation, it is not an 'error' to include households who are marginally better-off - at least according to asset-based measurements - but rather a justifiable intent to extend coverage (Lind et al. 2018).

Thus, thinking about governance from below matters for a host of reasons. As the examples highlighted here show, it provides an alternative perspective on what are mundanely referred to as delivery 'challenges' local practices that diverge from official guidance for reasons that cannot be simply put down to insufficient training, funding or other capacity limitations (although they are often wrongly attributed to such). In doing so, it shifts attention to understanding how influence operates at the local level, through which connections, and the rationalities (or logics) for decisions influencing how social assistance is delivered.

\section{Conclusion}

Local agency in the delivery of social assistance shapes the policy process itself as much as actors and dynamics that happen in the realm of 'official politics' at the national level. This results in kaleidoscopic practices and the adaptation of formal ideas of delivery to suit local realities and power relations. Implementation is not simply a technical exercise of following a sequential series of interlinked steps, but rather a political process of negotiation and recalibration. It follows that improvements in the delivery of social assistance are not guaranteed by investments in preparing additional guidance or training for sub-national and local-level implementers, the creation of new structures dedicated to particular delivery components, or recommendations for coordination. Strengthening the implementation of social assistance is just as likely (if not more so) to emerge from greater understanding of local politics and governance than from training, and hence discovering ways to navigate the complexity of social and political relationships on the ground.

The concepts and approaches reviewed in this paper help to illuminate the 'real implementation or delivery' of social assistance - how it is targeted, taxed, diverted, and shared - and key questions about how it is provided, in whose interests, and with what impacts for poverty and vulnerability. For example, which subnational and local public authorities are involved in delivering social assistance? What are the governance relations between these authorities and actors and political entrepreneurs at the centre? Who are local public authorities accountable to and how? How do centre-local relations, as well as accountability relations for various local public authorities, bear on implementation decisions (including who to include and exclude)? How do local public authorities respond to what is often low coverage of safety nets and other state-led social assistance and levels of need that dwarf the assistance that is available? And how does the provision of different forms of social assistance - as something entwining with negotiations between and among a range of public authorities at different levels - relate to the political marketplace and shifts in power?

Other questions relate to populations that are meant to be 'assisted' and otherwise 'protected': how do populations in FCAS perceive the provision of social assistance? To what extent are social transfers shared? How significant is social assistance compared to how else people get by? How do people interact with a range of providers? Do they differentiate between different types of assistance that are given? How does the receipt of social assistance influence public attitudes toward various public authorities, if at all?

These sorts of questions matter because technocratic approaches often gloss over politics and miss the ways in which programmed types of social assistance exclude people, as well as how social transfers are widely shared, often diverted, and taxed. All of this ultimately matters for effectiveness: absent greater 
understanding of the local politics and governance of social assistance, it is impossible to know who is getting what and the channels of influence that might encourage the most inclusive and accountable types of distribution. Social assistance that engages more meaningfully with local politics, analyses local governance relations more carefully, and reflects on what that means for the design of targeting, delivery, monitoring, and accountability processes will be more effective and provide better value for money. 


\section{References}

Abdulai, A.G. (2021) 'Competitive Clientelism, Donors and the Politics of Social Protection Uptake in Ghana', Critical Social Policy 41.2: 270-93

Barrientos, A. and Pellissery, S. (2012) Delivering Effective Social Assistance: Does Politics Matter? ESID Working Paper No. 9. Manchester: Effective States and Inclusive Development Research Centre, University of Manchester

Bell, C. and Pospisil, J. (2017) 'Navigating Inclusion in Transitions from Conflict: The Formalised Political Unsettlement', Journal of International Development 29.5: 576-93

Bierschenk, T. and Olivier de Sardan, J.P. (2019) 'How to Study Bureaucracies Ethnographically?', Critique of Anthropology 39.2: 243-57

Boone, C. (2003) Political Topographies of the African State: Territorial Authority and Institutional Choice, Cambridge: Cambridge University Press

Booth, D. (2012) Development as a Collective Action Problem: Addressing the Real Challenges of African Governance, Synthesis Report of the Africa Power and Politics Programme, London: Overseas Development Institute (accessed 15 April 2021)

Carbonnier, G. (2015) Humanitarian Economics: War, Disaster and the Global Aid Market, Oxford: Oxford University Press

Centre for Public Authority and International Development (2021) 'About CPAID', Centre for Public Authority and International Development, London School of Economics (accessed 11 January 2022)

Cetinoglu, T. and Yilmaz, V. (2020) 'A Contextual Policy Analysis of a Cash Programme in a Humanitarian Setting: The Case of the Emergency Social Safety Net in Turkey', Disasters 45.3: 604-26

Cherrier, C. (2020) 'Domestic Resource Mobilization for Social Transfers in Sub-Saharan Africa: Can Foreign Aid Act as a Catalyst?', in K. Hujo (ed), The Politics of Domestic Resource Mobilization for Social Development, Cham: Palgrave Macmillan

Cuevas, P.F.; Inan, O.K.; Twose, A. and Celik, C. (2019) Vulnerability and Protection of Refugees in Turkey: Findings From the Rollout of the Largest Humanitarian Cash Assistance Program in the World, Washington DC: World Bank

Czuba, K. (2019) 'Karamojan Politics: Extension of State Power and Formation of a Subordinate Political Elite in Northeastern Uganda', Third World Quarterly 40.3: 558-77

de Waal, A. (2016) 'Introduction to the Political Marketplace for Policymakers', JSRP Policy Brief, No 1, London: Justice and Security Research Programme, London School of Economics (accessed 15 April 2021)

de Waal, A. (2015) The Real Politics of the Horn of Africa: Money, War and the Business of Power, Cambridge: Polity

de Waal, A. (2014) The Political Marketplace: Analyzing Political Entrepreneurs and Political Bargaining with a Business Lens, World Peace Foundation, 17 October (accessed 11 January 2022)

de Waal, A.; Sarkar, A. and Newton, C. (2021) 'Transactional Politics and Humanitarian Crisis: Lessons for Policy From the Political Marketplace Framework', Conflict Research Programme Policy Brief, London: London School of Economics (accessed 11 January 2022)

Devereux, S. (2020) Policy Pollination: A Brief History of Social Protection's Brief History in Africa, IDS Working Paper 543, Brighton: Institute of Development Studies, DOI: 10.19088/IDS.2020.004 (accessed 11 January 2022)

Donovan, K.P. (2015) 'Infrastructuring Aid: Materializing Humanitarianism in Northern Kenya', Environment and Planning D: Society and Space 33.4: 732-48

Duffield, M. (2007) Development, Security and Unending War: Governing the World of Peoples, Cambridge: Polity 
Duffield, M. (1994) 'The Political Economy of Internal War: Asset Transfer, Complex Emergencies, and International Aid', in J. Macrae and A. Zwi (eds), War and Hunger: Rethinking International Responses to Complex Emergencies, London: Zed Books

Enria, L. (2020) 'Unsettled Authority and Humanitarian Practice: Reflections on Local Legitimacy From Sierra Leone's Borderlands', Oxford Development Studies 48.4: 387-99

Gaventa, J. and Oswald, K. (2019) Empowerment and Accountability in Difficult Settings: What Are We Learning? Key Messages Emerging from the Action for Empowerment and Accountability Programme, Brighton: Institute of Development Studies

Gentilini, U. et al. (2021) 'Social Protection and Jobs Responses to COVID-19: A Real-Time Review of Country Measures', 'Living paper' Version 15, 14 May 2021, Washington DC: World Bank (accessed 16 May 2021)

Grimm, M.; Hartwig, R.; Reitmann, A.K. and Bocoum, F.Y. (2021) 'Inter-Household Transfers: An Empirical Investigation of the Income-Transfer Relationship With Novel Data From Burkina Faso', World Development 144: 105486

Harvey, P. and Mohamed, H. (2021) 'Draft Paper for the BASIC Research Programme', Brighton: Institute of Development Studies

Hickey, S.; Lavers, T.; Niño-Zarazúa, M. and Seekings, J. (2019) 'The Negotiated Politics of Social Protection in East and Southern Africa', in S. Hickey, T. Lavers, M. Niño-Zarazúa and J. Seekings (eds), The Politics of Social Protection in Eastern and Southern Africa, Oxford: Oxford University Press

Hoddinott, J. et al. (2013) 'Implementing Large Scale Food Security Programs in Rural Ethiopia: Insights from the Productive Safety Net Program', in D. Rahmato, A. Pankhurst and J.G. van Uffelen (eds), Food Security, Safety Nets and Social Protection in Ethiopia, Addis Ababa: Forum for Social Studies

Hoffmann, K.; Vlassenroot, K.; Carayannis, T. and Muzalia, G. (2020) 'Violent Conflict and Ethnicity in the Congo: Beyond Materialism, Primordialism and Symbolism', Conflict, Security and Development 20.5: 539-60

Hoffmann, K. and Kirk, T. (2013) Public Authority and the Provision of Public Goods in Conflict-Affected and Transitioning Regions, JSRP Paper No. 7, London: Justice and Security Research Programme, London School of Economics (accessed 14 April 2021)

Jaspars, S. (2018) Food Aid in Sudan: A History of Power, Politics and Profit, London: Zed Books

Jaspars, S.; Adan, G.M. and Majid, N. (2020) Food and Power in Somalia: Business as Usual? A Scoping Study on the Political Economy of Food Following Shifts in Food Assistance and in Governance, London: Conflict Research Programme, London School of Economics and Political Science (accessed 13 January 2022)

Kaldor, M. and de Waal, A. (2020) 'Identity Formation and the Political Marketplace', Conflict, Security and Development 20.5: 519-38

Keeley, J. and Scoones, I. (2000) 'Knowledge, Power and Politics: The Environmental Policy-Making Process in Ethiopia', Journal of Modern African Studies 38.1: 89-120

Keen, D. (2008) Complex Emergencies, Cambridge: Polity

Keen, D. (1994) The Benefits of Famine. A Political Economy of Famine and Relief in South Western Sudan 1983-89, Oxford: James Currey

Kirk, T. (2021) How a 'Public Authority' Lens Can Help Us Understand NGOs and INGOs, Centre for Public Authority and International Development blog, 5 March, London School of Economics (accessed 11 January 2022)

Lavers, T. (2020) State Infrastructural Power and Social Transfers: The Local Politics of Distribution and Delivering 'Progress' in Ethiopia, ESID Working Paper No 147, Manchester: Effective States and Inclusive Development Research Centre, University of Manchester 
Lavers, T. and Hickey, S. (2020) Alternative Routes to the Institutionalisation of Social Transfers in SubSaharan Africa: Political Survival Strategies and Transnational Policy Coalitions, ESID Working Paper No 138, Manchester: Effective States and Inclusive Development Research Centre, University of Manchester

Lavers, T. and Hickey, S. (2016) 'Conceptualising the Politics of Social Protection Expansion in Low Income Countries: The Intersection of Transnational Ideas and Domestic Politics', International Journal of Social Welfare 25.4: 388-98

Lavers, T.; Mohammed, D. and Selassie, B.W. (2020) The Politics of Distributing Social Transfers in Afar, Ethiopia: The Intertwining of Party, State and Clan in the Periphery, ESID Working Paper No 141, Manchester: Effective States and Inclusive Development Research Centre, University of Manchester

Lind, J.; Sabates-Wheeler, R.; Hoddinott, J. and Taffesse, A. (2018) Targeting Social Transfers in Pastoralist Societies, Strategy Support Program Working Paper No 124, Addis Ababa: International Food Policy Research Institute

Lindert, K.; Karippacheril, T.G.; Rodriguez Caillava, I. and Nishikawa Chávez, K. (eds) (2020) Sourcebook on the Foundations of Social Protection Delivery Systems, Washington DC: World Bank (accessed 13 January 2022)

Lund, C. (2006) 'Twilight Institutions: Public Authority and Local Politics in Africa', Development and Change 37.4: 685-705

Markakis, J.; Schlee, G. and Young, J. (2021) The Nation State: A Wrong Model for the Horn of Africa, Berlin: Max-Planck-Gesellschaft zur Förderung der Wissenschaften

Meagher, K. (2012) 'The Strength of Weak States? Non-State Security Forces and Hybrid Governance in Africa', Development and Change 43.5: 1073-1101

Meagher, K.; De Herdt, T. and Titeca, K. (2014) 'Unravelling Public Authority: Paths of Hybrid Governance in Africa', IS Academy Research Brief No 10, London and Antwerp: London School of Economics and the University of Antwerp (accessed 14 April 2021)

Menkhaus, K. (2008) 'The Rise of a Mediated State in Northern Kenya: The Wajir Story and its Implications for State-Building', Afrika Focus 21.2: 23-38

Newton, C.; Mawien, B.; Madut, C.; Gray, E. and Pendle, N. (2021) Chiefs' Courts, Hunger, and Improving Humanitarian Programming in South Sudan, London: Conflict Research Programme, London School of Economics and Political Science (accessed 13 January 2022)

Nikolov, P. and Bonci, M. (2020) 'Do Public Program Benefits Crowd Out Private Transfers in Developing Countries? A Critical Review of Recent Evidence', World Development 134: 104967

Olivier de Sardan, J.P. (2011) 'Local Powers and the Co-Delivery of Public Goods in Niger', IDS Bulletin 42.2: $32-42$

Piketty, T. (2018) Capital in the Twenty-First Century, Cambridge MA: Harvard University Press

Porisky, A. (2020) The Distributional Politics of Social Transfers in Kenya, ESID Working Paper No 155, Manchester: Effective States and Inclusive Development Research Centre, University of Manchester

Pruce, K. (2019) 'Investigating the Politics of Global Policy Transfer: The Case of Social Protection in Zambia', unpublished doctoral dissertation, University of Manchester

Rettberg, S. (2020) 'Shifting Regimes of Violence Within Ethiopia's Awash Valley Investment Frontier', in J. Lind, D. Okenwa and I. Scoones (eds), Land, Investment\& Politics: Reconfiguring Eastern Africa's Pastoral Drylands, Woodbridge UK: James Currey

Sabates-Wheeler, R.; Lind, J. and Hoddinott, J. (2013) 'Implementing Social Protection in AgroPastoralist and Pastoralist Areas: How Local Distribution Structures Moderate PSNP Outcomes in Ethiopia', World Development 50: 1-12

Samuelsen, H. (2020) 'Accelerated Fragility: Exploring the Supply-Demand Nexus in Health Facilities in Rural Burkina Faso', Africa: The Journal of the International African Institute 90.5: 934-51 
Sansculotte-Greenidge, K. and Fantaye, D. (2012) 'Traditional Authority and Modern Hegemony: Peacemaking in the Afar Region of Ethiopia', in M. Mutisi and K. Sansculotte-Greenidge (eds), Integrating Traditional and Modern Conflict Resolution: Experiences from Selected Cases in Eastern and the Horn of Africa, African Dialogue Monograph Series No 2/2012

Slater, R. and Sabates-Wheeler, R. (2021) 'Defining Social Assistance for the BASIC Research Programme: Internal Guidance Note', unpublished paper, BASIC Research programme

Tria Kerkvliet, B.J. (2009) 'Everyday Politics in Peasant Societies (and Ours)', The Journal of Peasant Studies 36.1: 227-43

Unsworth, S. (2010) An Upside Down View of Governance, Centre for the Future State, Brighton: Institute of Development Studies

Vaismoradi, M.; Turunen, H. and Bondas, T. (2013) 'Content Analysis and Thematic Analysis: Implications for Conducting a Qualitative Descriptive Study', Nursing and Health Sciences 15.3: 398-405

van den Boogaard, V. and Santoro, F. (2021) Explaining Informal Taxation and Revenue Generation: Evidence from South-Central Somalia, ICTD Working Paper No 118, Brighton: International Centre for Tax and Development, Institute of Development Studies, DOI: 10.19088/ICTD.2021.003 (accessed 11 January 2022)

Zaman, T. et al. (2021) 'Draft Paper for the BASIC Research Programme', Brighton: Institute of Development Studies 


\section{Acknowledgements and Disclaimer}

This document was developed by the Better Assistance in Crises (BASIC) Research programme. BASIC is implemented by the Institute of Development Studies (IDS), the University of Sussex and the Centre for International Development and Training, funded by UKAid from the UK government. The views expressed in this document are entirely those of the authors and do not necessarily represent views or policies of the UK governments official policies.

() IDS copyright 2022. Copyright in the typographical arrangement and design rests with IDS.

This publication (excluding the logos) may be reproduced free of charge in any format or medium, provided that it is reproduced accurately and not used in a misleading context. The material must be acknowledged as IDS copyright with the title and source of the publication specified.

Published by IDS.

\section{Suggested citation}

Lind, J. (2022) Politics and Governance of Social Assistance in Crises from the Bottom Up, BASIC Research Working Paper 4, Brighton: Institute of Development Studies, DOI: 10.19088/BASIC.2022.004 